\title{
Anti-hyperlipidemic effects of Caralluma edulis (Asclepiadaceae) and Verbena officinalis (Verbenaceae) whole plants against high-fat diet-induced hyperlipidemia in mice
}

\author{
Aqsa Ashfaq ${ }^{1}$, Arif-ullah Khan¹, Amber Mahmood Minhas', Tahir Aqeel ${ }^{2}$, Asaad \\ M Assiri ${ }^{3}$ and Ishfaq A Bukhari ${ }^{4 *}$ \\ ${ }^{1}$ Department of Pharmacology, Riphah Institute of Pharmaceutical Sciences, Riphah International University, Islamabad, \\ ${ }^{2}$ Department of Pharmacy, University of Lahore, Islamabad Campus, Lahore, Pakistan, ${ }^{3}$ Prince Abdullah Ben Khalid Celiac \\ Disease Research Chair, Department of Pediatrics, Faculty of Medicine, ${ }^{4}$ Pharmacology Section, College of Medicine, King \\ Saud University, Riyadh, Saudi Arabia
}

*For correspondence: Email: iabukhari@ksu.edu.sa

Sent for review: 7 May 2017

Revised accepted: 23 September 2017

\begin{abstract}
Purpose: To investigate the anti-hyperlipidemic effect of Caralluma edulis and Verbena officinalis. Methods: Phytochemical analysis of crude extracts of Caralluma edulis (Ce.Cr) and Verbena officinalis (Vo.Cr) were carried out. Hyperlipidemia was induced in mice with high-fat diet (HFD, $1.25 \% \mathrm{w} / \mathrm{w}$ cholesterol, $0.5 \% \mathrm{w} / \mathrm{w}$ cholic acid and $10 \% \mathrm{v} / \mathrm{w}$ coconut oil). All the groups, except the saline-treated group, were fed on HFD for 4 weeks (lead-in period) to induce hyperlipidemia. Thereafter, the groups were treated with varying doses of the plant extract for 2 weeks (treatment period) as well as atorvastatin $(10 \mathrm{mg} / \mathrm{kg})$ reference standard. Body weight was measured fortnightly for all groups. Total cholesterol (TC), triglyceride (TGs) and low density lipoprotein (LDL) were assayed using Merck diagnostic kits. For histopathological analysis, liver slices were fixed in $10 \%$ formalin and embedded in paraffin wax and was examined with the aid of hematoxylin and eosin staining ( $H$ \& E).

Results: Caralluma edulis (Ce.Cr) contains saponins, alkaloids, tannins, phenol, glycosides, terpenoids and flavonoids while Verbena officinalis (Vo.Cr) tested positive for the presence of alkaloids, carbohydrates, flavonoids, saponins and tannins. HFD increased total cholesterol (TC), triglyceride (TGs), low density lipoprotein ( $L D L$ ) and very low density lipoprotein (VLDL) compared to regulator diet ( $p<0.001)$. Treatment of the animals with Ce.Cr and Vo.Cr dose-dependently (500 - $1000 \mathrm{mg} / \mathrm{kg})$ reduced serum TC, TGs, LDL and VLDL ( $p<0.05, p<0.01, p<0.001$, vs. HFD group) and raised high density lipoprotein (HDL) ( $p<0.01$, vs. HFD group), similar to that observed with atorvastatin (10 $\mathrm{mg} / \mathrm{kg}$ ). The anti-hyperlipidemic effects of Ce.Cr and $\mathrm{Vo}$.Cr were also confirmed via liver histopathology results, showing improved structure with no hepatocellular necrosis and fat accumulation.

Conclusion: These results indicate that Caralluma edulis and Verbena officinalis exhibit antihyperlipidemic effect; thus, the plants have therapeutic potentials for the management of lipid disorders.
\end{abstract}

Keywords: Caralluma edulis, Verbena officinalis, Anti-hyperlipidemia, Hepatocellular necrosis

Tropical Journal of Pharmaceutical Research is indexed by Science Citation Index (SciSearch), Scopus, International Pharmaceutical Abstract, Chemical Abstracts, Embase, Index Copernicus, EBSCO, African Index Medicus, JournalSeek, Journal Citation Reports/Science Edition, Directory of Open Access Journals (DOAJ), African Journal Online, Bioline International, Open-J-Gate and Pharmacy Abstracts

\section{INTRODUCTION}

Hyperlipidemia leads to the progression of various cardiovascular complications, such as atherosclerosis, myocardial infarction and hypertension [1]. Various types of lipids such as total cholesterol (TC), triglyceride (TGs), high density lipoprotein (HDL), and low density 
lipoprotein (LDL), very low density lipoproteins (VLDL) cause various health problems such as pancreatitis and cardiovascular disorders [2]. It has been reported that about one fourth of the people suffering from myocardial infarction had hyperlipidemia [3]. Effective management of hyperlipidemia reduces the risk of cardiovascular events. Current therapy for hyperlipidemia management includes statins, fibrates, and bile acid sequestrates but the use of these drugs has been associated with many side effects. Medicinal plants enriched in phytochemicals such as tannins, saponins, flavonoids, essential oils and alkaloids have curative properties and are used in the traditional system of medicine for the management of various ailments [4]. Oxidative stress plays an important role in the onset of hyperlipidemia due to free radical generation, which leads to the further progression of cardiovascular diseases [5]. Medicinal plants being rich in antioxidant constituents possess profound antioxidant properties.

Caralluma edulis commonly known as "Choung" belongs to family Asclepiadaceae. Genus Caralluma enriched in pregnane glycosides, megastigmane glycosides, flavone and esters [6]. Caralluma edulis is known to possess antidiabetic [7] and antioxidant [8] properties.

Verbena officinalis commonly known as "Vervian", "Herb of grace" belongs to family Verbenaceae [9]. Verbena officinalis contain various irridoids such as verbenalin and hastatoside which possess antioxidant properties [10]. In the current investigation we evaluated anti-hyperlipidemic activity of Caralluma edulis and Verbena officinalis using high fat diet (HFD) animal model to explore their use in the treatment of hyperlipidemia.

\section{EXPERIMENTAL}

\section{Plant material and extraction}

The whole plant Caralluma edulis was purchased from a local market in May and the whole plant of Verbena officinalis was collected from Rawat, Islamabad, Pakistan. The plant samples were identified from Dr. Mushtaq Ahmad at Plant Sciences Department, Quaid-i-Azam University, Islamabad. The sample specimen bearing voucher number ISB-422 and ISB-270 were deposited to the herbarium of same department. The plants were thoroughly washed, shade dried at room temperature and coarsely ground. The Caralluma edulis powdered material $(3 \mathrm{~kg})$ was treated with $80 \%$ aqueous-ethanol for seven days and Verbena officinalis grinded powder (2.7 $\mathrm{kg}$ ) was soaked in $70 \%$ methanol for 14 days, with ocassional shaking and mixing. Both the plant materials were filtered through grade 1 Whatmann filter paper [11]. The filtered materials were concentrated on rotary evaporator to obtain a thick semi-solid paste i.e. Caralluma edulis crude extract (Ce.Cr) and Verbena officinalis crude extract (Vo.Cr), yielding approximately $4.67 \%(\mathrm{w} / \mathrm{w})$ and $18.66 \%(\mathrm{w} / \mathrm{w})$ respectively. The crude extracts were solubilized in normal saline.

\section{Chemicals}

Cholic acid and cholesterol were purchased from Sigma Chemicals (Germany), atorvastatin from Getz Pharmaceuticals, Karachi Pakistan and crude coconut oil procured from Marhaba lab, Pvt Ltd. Lahore. Analytical grade chemicals were used. TC, TGs and HDL diagnostic kits were purchased from Merck (Japan).

\section{Animals}

Balb-C mice (25 - $35 \mathrm{~g}$ ) were used in the study and placed at Animal House of the Riphah Institute of Pharmaceutical Sciences, where controlled environmental conditions were maintained at $25 \pm 2^{\circ} \mathrm{C}$ temperature, $12 \mathrm{~h}$ light and dark cycle with free access to standard diet and tap water ad libitum. Animal experiments were performed in accordance with "Principles of Laboratory Animal care" (NIH publication 85-23, revised 1985) [12] approved by Ethics Committee of Riphah Institute of Pharmaceutical Sciences (ref. no. REC/RIPS/2016/001).

\section{Phytochemical characterization}

The phytochemical analysis was performed according to the standard protocols [13] with slight modifications.

\section{Induction of hyperlipidemia}

Hyperlipidemia was induced by feeding on high fat diet $(1.25 \% \mathrm{w} / \mathrm{w}$ cholesterol, $0.5 \% \mathrm{w} / \mathrm{w}$ cholic acid and $10 \% \mathrm{v} / \mathrm{w}$ coconut oil with slight modifications [14]. The period of 4 week was considered as the lead-in period to induce hyperlipidemia in mice while in the next two week period treatment was done with different doses of plant. Body weights were measured after every two week for all groups.

\section{Anti-hyperlipidemic activity}

Balb-C mice were divided into seven groups each consisting of six animals. Group 1 served as regular diet control treated orally with saline 
(10 mL/kg). Group 2 received only HFD. Group 3 and 4 received $\mathrm{Ce} . \mathrm{Cr}$ at the dose of 500 and $1000 \mathrm{mg} / \mathrm{kg}$ respectively along with HFD. Group 5 and 6 received Vo.Cr at the dose 500 and 1000 $\mathrm{mg} / \mathrm{kg}$ respectively along with HFD. Group 7 received atorvastatin dose $10 \mathrm{mg} / \mathrm{kg}$ with HFD. All the doses were given through oral route (p.o).

\section{Determination of hyperlipidemia}

The blood sample (1 $\mathrm{mL})$ was collected using disposable syringe via cardiac puncture and allowed to clot at room temperature in sterile gel tubes for $45 \mathrm{~min}$. The plasma was separated through centrifugation at $3000 \mathrm{rpm}$ for $10 \mathrm{~min}$ and the samples were analyzed spectrophotometrically. TC, TGs and HDL were assayed using Merck diagnostic kits. LDL and VLDL concentrations were measured using Fridewald's equations as in Eqs 1 and 2, respectively [15].

$\mathrm{VLDL}=(\mathrm{TGs}) / 5$

$\mathrm{LDL}=\mathrm{TC}-(\mathrm{HDL})-(\mathrm{VLDL})$

\section{Body weight measurement}

Body weight was measured initially, then after every two weeks for all the groups.

\section{Histopathological analysis}

Liver slices were fixed in $10 \%$ formalin and embedded in paraffin wax and histopathological analysis of liver samples studied through Hematoxylin and Eosin staining ( $\mathrm{H} \& \mathrm{E})$.

\section{Statistical analysis}

Data expressed as Mean \pm SEM (standard error of mean). Results were analyzed using one-way analysis of variance (ANOVA) followed by posthoc Tukey test. $P<0.05$ was considered significant.

\section{RESULTS}

\section{Phytochemical profile}

The phytochemical analysis revealed that $\mathrm{Ce} . \mathrm{Cr}$ contains saponins, alkaloids, tannin, phenol, glycosides, terpenoids and flavonoids. While Vo.Cr indicates the presence of for alkaloids, carbohydrates, flavonoids, saponins and tannins.

\section{Effect of Ce.Cr and Vo.Cr on TC}

Ce.Cr and Vo.Cr dose-dependently (500 - 1000 $\mathrm{mg} / \mathrm{kg}$ ) reduce the HFD-induced raise in level of TC (Table 1). In saline treated group, TC value was $92.8 \pm 8.66 \mathrm{mg} / \mathrm{dL}$. HFD treatment raised level of TC to $386.2 \pm 21.82 \mathrm{mg} / \mathrm{dL}(p<0.001 \mathrm{vs}$. saline group). Treatment of groups with Ce.Cr at the dose of 500 and $1000 \mathrm{mg} / \mathrm{kg}$ for two weeks reduced TC level to $305.4 \pm 6.72$ and $287.8 \pm$ $16.85 \mathrm{mg} / \mathrm{dL}$ ( $p<0.01 ; p<0.001 \mathrm{vs}$. HFD group) respectively. Similarly Vo.Cr at 500 and 1000 $\mathrm{mg} / \mathrm{kg}$ reduced TC level from $386.2 \pm 21.82$ $\mathrm{mg} / \mathrm{dL}$ to $165 \pm 14.47$ and $116.8 \pm 9.82 \mathrm{mg} / \mathrm{dL}(p$ $<0.001 ; p<0.001$ vs. HFD group) respectively. Atorvastatin $(10 \mathrm{mg} / \mathrm{kg})$ reduces TC level to $161.4 \pm 9.47 \mathrm{mg} / \mathrm{dL}(p<0.001$ vs. HFD group.

\section{Effect of Ce.Cr and Vo.Cr on TGs}

Ce.Cr and Vo.Cr dose-dependently (500 - 1000 $\mathrm{mg} / \mathrm{kg}$ ) reduced the HFD induced increased level of TGs (Table 1). TGs value of saline treated group was $86.6 \pm 6.85 \mathrm{mg} / \mathrm{dL}$. Treatment of mice with HFD raised level of TGs to $162 \pm 14.21$ $\mathrm{mg} / \mathrm{dL}$ ( $p<0.001$ vs. saline group). Ce.Cr at doses of 500 and $1000 \mathrm{mg} / \mathrm{kg}$ reduced TGs level to $139.2 \pm 11.35 \mathrm{mg} / \mathrm{dL}$ and $125.4 \pm 6.72 \mathrm{mg} / \mathrm{dL}$ respectively ( $p<0.05$ vs. HFD group) as shown in Table 1, Vo.Cr (500 and $1000 \mathrm{mg} / \mathrm{kg}$ ) caused significant reduction in the HFD-induced increased level of TGs in rats plasma. In atorvastatin $(10 \mathrm{mg} / \mathrm{kg})$ treated group, TGs level value was $114.4 \pm 8.08 \mathrm{mg} / \mathrm{dL}(p<0.05$ vs. HFD group).

Table 1: Inhibitory effect of Caralluma edulis crude extract (Ce.Cr) and Verbena officinalis crude extract (Vo.Cr) against high fat diet (HFD)-induced increase in total cholesterol (TC), triglycerides (TGs), high density lipoprotein (HDL) and low density lipoprotein (LDL) in mice

\begin{tabular}{|c|c|c|c|c|}
\hline Treatment & $\mathrm{TC}(\mathrm{mg} / \mathrm{dL})$ & TGs (mg/dL) & $\mathrm{HDL}(\mathrm{mg} / \mathrm{dL})$ & LDL (mg/dL) \\
\hline Saline $(10 \mathrm{~mL} / \mathrm{kg})$ & $92.8 \pm 8.66$ & $86.6 \pm 6.85$ & $33.4 \pm 2.16$ & $41.6 \pm 7.09$ \\
\hline HFD & $386.2 \pm 21.82^{\#}$ & $162 \pm 14.21^{\#}$ & $32 \pm 2.608$ & $317.4 \pm 23.37^{\#}$ \\
\hline HFD + Ce.Cr (500 mg/kg) & $305.4 \pm 6.72^{\pi x}$ & $139.2 \pm 11.35^{\pi}$ & $51.2 \pm 2.26$ & $229.6 \pm 6.34$ \\
\hline $\mathrm{HFD}+\mathrm{Ce} . \mathrm{Cr}(1000 \mathrm{mg} / \mathrm{kg})$ & $287.8 \pm 16.85^{\prime}$ & $125.4 \pm 6.72$ & $51.8 \pm 3.08$ & $210.6 \pm 18.53$ \\
\hline HFD + Vo.Cr $(500 \mathrm{mg} / \mathrm{kg})$ & $165 \pm 14.47$ & $148 \pm 10.83$ & $49 \pm 0.83$ & $86 \pm 15.64$ \\
\hline HFD + Vo.Cr (1000 mg/kg) & $116.8 \pm 9.82^{\cdots}$ & $82.8 \pm 6.39$ & $50.8 \pm 0.66$ & $49 \pm 9.36$ \\
\hline HFD + Atorvastatin $(10 \mathrm{mg} / \mathrm{kg})$ & $161.4 \pm 9.47^{\pi \pi \pi}$ & $114.4 \pm 8.08^{*}$ & $49 \pm 1.51^{\pi \pi}$ & $89 \pm 9.70$ \\
\hline
\end{tabular}




\section{Effect of Ce.Cr and Vo.Cr on HDL}

Ce.Cr and Vo.Cr increased the level of HDL in dose-dependent (500 - $1000 \mathrm{mg} / \mathrm{kg}$ ) manner (Table 1). The HDL level of saline treated group was $33.4 \pm 2.16 \mathrm{mg} / \mathrm{dL}$. In HFD treatment group, the level of HDL was $32 \pm 2.608 \mathrm{mg} / \mathrm{dL}(p>0.05$ vs. saline group). Ce.Cr at dose of 500 and 1000 $\mathrm{mg} / \mathrm{kg}$ caused significant ( $p<0.01$ vs. HFD group) increase in the HDL level to $51.2 \pm 2.26$ $\mathrm{mg} / \mathrm{dL}$ and $51.8 \pm 3.08 \mathrm{mg} / \mathrm{dL}$ respectively $(p<$ 0.01 vs. HFD group). Similar results were obtained in groups treated with $\mathrm{Vo} . \mathrm{Cr}$ (500 and $1000 \mathrm{mg} / \mathrm{kg})$. In atorvastatin $(10 \mathrm{mg} / \mathrm{kg})$ treated group, $\mathrm{HDL}$ level value was $49 \pm 1.51 \mathrm{mg} / \mathrm{dL}(p<$ 0.01 vs. HFD group).

\section{Effect of Ce.Cr and Vo.Cr on LDL}

Ce.Cr and Vo.Cr dose-dependently (500 - 1000 $\mathrm{mg} / \mathrm{kg}$ ) reduced the HFD-induced raise in level of LDL (Table 1). In saline treated group, LDL value was $41.6 \pm 7.09 \mathrm{mg} / \mathrm{dL}$. HFD treatment raised level of LDL to $317.4 \pm 23.37 \mathrm{mg} / \mathrm{dL}(p<0.001$ vs. saline group). Ce.Cr (500 and $1000 \mathrm{mg} / \mathrm{kg}$ ) reduced LDL level to $229.6 \pm 6.34 \mathrm{mg} / \mathrm{dL}(p<$ 0.01 vs. HFD group) and $210.6 \pm 18.53 \mathrm{mg} / \mathrm{dL}(p$ $<0.001$ vs. HFD group) respectively. $\mathrm{Vo} . \mathrm{Cr}$ (500 and $1000 \mathrm{mg} / \mathrm{kg}$ ) produced marked reduction in the LDL level to $86 \pm 15.64 \mathrm{mg} / \mathrm{dL}$ ( $p<0.001 \mathrm{vs}$. HFD group) and $49 \pm 9.36 \mathrm{mg} / \mathrm{dL}(p<0.001 \mathrm{vs}$. HFD group) respectively. Similarly atorvastatin $(10 \mathrm{mg} / \mathrm{kg})$ produced significant reduction in the LDL level up to $89 \pm 9.70 \mathrm{mg} / \mathrm{dL}(p<0.001 \mathrm{vs}$. HFD group).

\section{Effect of Ce.Cr and Vo.Cr on VLDL}

Ce.Cr and Vo.Cr dose-dependently (500 - 1000 $\mathrm{mg} / \mathrm{kg}$ ) reduced the HFD induced raised in level of VLDL (Table 2). In saline treated group, VLDL value was $17 \pm 1.44 \mathrm{mg} / \mathrm{dL}$. HFD treatment raised level of VLDL to $32 \pm 2.90 \mathrm{mg} / \mathrm{dL}(p<$ 0.001 vs. saline group). In Ce.Cr (500 and 1000 $\mathrm{mg} / \mathrm{kg}$ ) treated groups, VLDL level reduced to $27.4 \pm 2.20 \mathrm{mg} / \mathrm{dL}$ and $24.6 \pm 1.28 \mathrm{mg} / \mathrm{dL}(p<$ 0.05 vs. HFD group) respectively. Vo.Cr at dose of 500 and $1000 \mathrm{mg} / \mathrm{kg}$ decreased VLDL level to $29.2 \pm 2.22 \mathrm{mg} / \mathrm{dL}$ ( $p<0.05 \mathrm{vs}$. HFD group) and $16 \pm 1.30 \mathrm{mg} / \mathrm{dL}(p<0.001$ vs. HFD group) respectively. Atorvastatin $(10 \mathrm{mg} / \mathrm{kg}$ ) reduced the VLDL level to $22.4 \pm 1.63 \mathrm{mg} / \mathrm{dL}(p<0.05$ vs. HFD group).

Table 2: Inhibitory effect of Caralluma edulis crude extract (Ce.Cr) and Verbena officinalis crude extract (Vo.Cr) against high fat diet (HFD)-induced increase in very low density lipoprotein (VLDL) in mice

\begin{tabular}{ll}
\hline Treatment & VLDL $(\mathrm{mg} / \mathrm{dL})$ \\
\hline Saline $(10 \mathrm{~mL} / \mathrm{kg})$ & $17.00 \pm 1.44$ \\
HFD & $32.00 \pm 2.90^{\#}$ \\
HFD + Ce.Cr $(500 \mathrm{mg} / \mathrm{kg})$ & $27.40 \pm 2.20$ \\
HFD + Ce.Cr $(1000 \mathrm{mg} / \mathrm{kg})$ & $24.60 \pm 1.28$ \\
HFD + Vo.Cr $(500 \mathrm{mg} / \mathrm{kg})$ & $29.20 \pm 2.22^{\star}$ \\
HFD + Vo.Cr $(1000 \mathrm{mg} / \mathrm{kg})$ & $16.00 \pm 1.30^{\star}$ \\
HFD + Atorvastatin $(10 \mathrm{mg} / \mathrm{kg})$ & $22.40 \pm 1.63^{\star}$ \\
\hline
\end{tabular}

Values expressed as mean \pm SEM $(n=5$ in each group); $"$ $p<0.001$ vs. saline group, $\stackrel{*}{p}<<0.05,{ }^{* * *} p<$ 0.001 vs. HFD treated group, one-way ANOVA with Tukey post-hoc test

\section{Effect of Ce.Cr and Vo. Cr on body weight}

Ce.Cr at 500 and $1000 \mathrm{mg} / \mathrm{kg}$ reduced the body weight of mice, while $\mathrm{Vo} . \mathrm{Cr}$ at 500 and 1000 $\mathrm{mg} / \mathrm{kg}$ doses does not cause any reduction of animal body weight at end of treatment as shown in Table 3.

\section{Histopathological features}

Hematoxylin and eosin staining clearly showed fatty liver of mice fed on HFD compared to the animas fed on regular diet. Deposition of fat in mice fed on HFD was decreased in animals treated with Ce.Cr (500 and $1000 \mathrm{mg} / \mathrm{kg}$ ). As shown in Figure 1, fat deposition was not seen in animals treated with $\mathrm{Vo} . \mathrm{Cr}$ (500 and $1000 \mathrm{mg} / \mathrm{kg}$ ) and atorvastatin $(10 \mathrm{mg} / \mathrm{kg})$.

The liver section of mice treated with saline group shows no fatty changes and composed of central vein surrounded by hepatic cords (Figure 1A). In HFD group, the liver showed central vein congestion and marked fatty change (Figure 1B).

Table 3: Effect of Caralluma edulis crude extract (Ce.Cr) and Verbena officinalis crude extract (Vo.Cr) on the body weight of high fat diet (HFD) administered mice

\begin{tabular}{lcccc}
\hline GROUPS & \multicolumn{4}{c}{ Body weight $(\mathbf{g})$} \\
\cline { 2 - 5 } & 0 week & $2^{\text {nd }}$ week & $4^{\text {th }}$ week & $6^{\text {th }}$ week \\
Saline $(10 \mathrm{~mL} / \mathrm{kg})$ & $29.3 \pm 1.17$ & $29.6 \pm 1.15$ & $29.9 \pm 1.09$ & $30.5 \pm 1.19$ \\
HFD & $31.1 \pm 1.09$ & $32.0 \pm 0.84$ & $33.6 \pm 0.81$ & $35.1 \pm 1.33$ \\
HFD + Ce.Cr $(500 \mathrm{mg} / \mathrm{kg})$ & $29.7 \pm 0.55$ & $30.8 \pm 0.72$ & $31.4 \pm 0.66$ & $30.1 \pm 0.86$ \\
HFD + Ce.Cr $(1000 \mathrm{mg} / \mathrm{kg})$ & $29.6 \pm 0.69$ & $30.3 \pm 0.75$ & $30.6 \pm 0.70$ & $29.2 \pm 0.40$ \\
HFD + Vo.Cr $(500 \mathrm{mg} / \mathrm{kg})$ & $31.4 \pm 0.80$ & $31.9 \pm 0.63$ & $32.4 \pm 0.71$ & $32.8 \pm 0.78$ \\
HFD + Vo.Cr $(1000 \mathrm{mg} / \mathrm{kg})$ & $32.6 \pm 0.59$ & $33.2 \pm 0.65$ & $33.8 \pm 0.70$ & $34.5 \pm 0.46$ \\
HFD + Atorvastatin $(10 \mathrm{mg} / \mathrm{kg})$ & $31.2 \pm 0.88$ & $32.4 \pm 0.70$ & $33.0 \pm 0.71$ & $33.3 \pm 0.72$ \\
\hline
\end{tabular}

Values expressed as mean $\pm \operatorname{SEM}(n=5)$ 

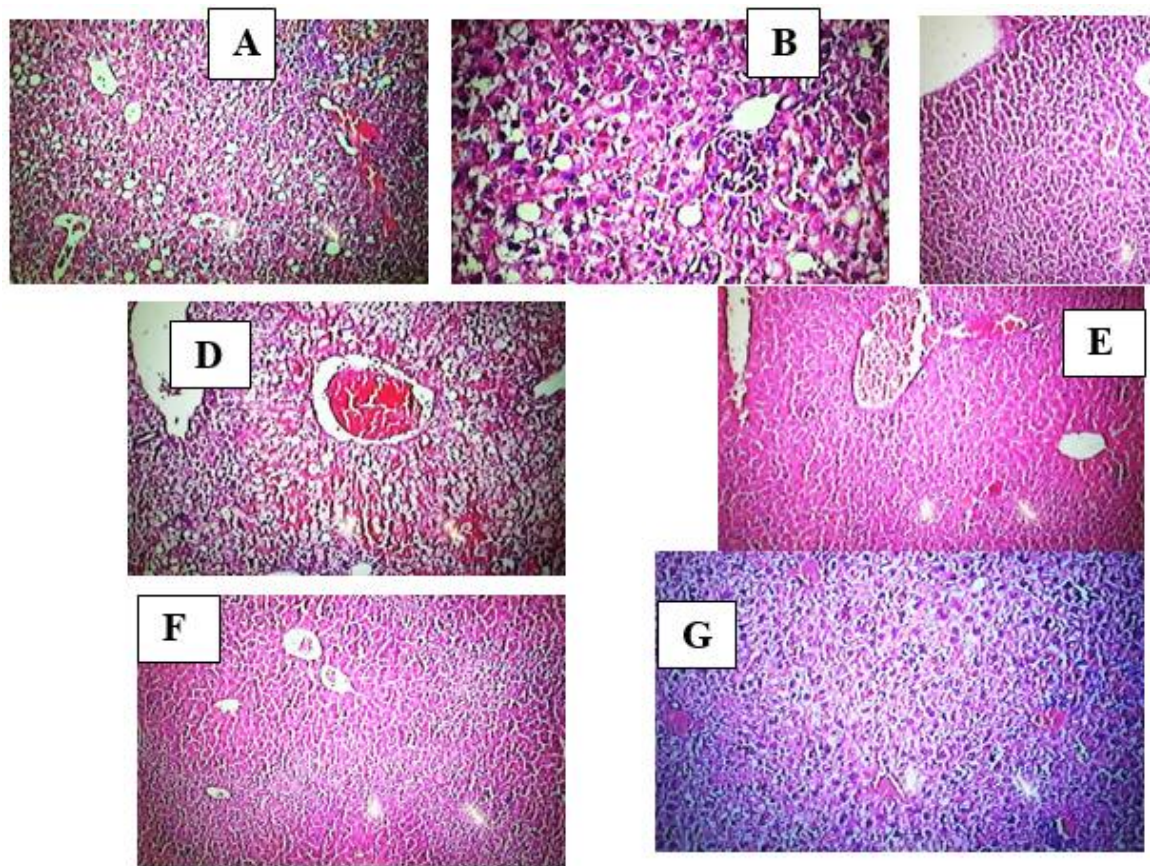

Figure 1: Representative micrographs (40x magnification, hematoxylin and eosin staining), showing effect of Caralluma edulis crude extract (Ce.Cr) and Verbena officinalis crude extract ( $\mathrm{Vo} . \mathrm{Cr}$ ) against HFD induced histopathological changes in mice liver. A. Saline $(10 \mathrm{~mL} / \mathrm{kg})$ treated liver tissue, showing normal central vein surrounded by hepatic cords with no fatty change. B. HFD intoxicated liver tissue, showing central vein congestion and marked fatty change. C. Ce.Cr $(500 \mathrm{mg} / \mathrm{kg})$ treated liver tissue, showing central vein congestion and moderate fatty change. D. Ce.Cr $(1000 \mathrm{mg} / \mathrm{kg})$ treated liver tissue, showing central vein congestion and mild fatty change. E. Vo.Cr $(500 \mathrm{mg} / \mathrm{kg})$ treated liver showing portal vein congestion and periportal hepatocytes drop out with no fatty change. F. Vo. $\mathrm{Cr}(1000 \mathrm{mg} / \mathrm{kg})$ treated liver showing periportal hepatocytes drop out with no fatty change. G. Atorvastatin $(10 \mathrm{mg} / \mathrm{kg})$ treatment showing portal vein congestion and hepatocytes drop out with no fatty change

In the Ce.Cr $(500 \mathrm{mg} / \mathrm{kg})$ treated animals, the liver tissue showed central vein congestion and moderate fatty change (Figure 1C).

Animals treated with a higher dose of $\mathrm{Ce} . \mathrm{Cr}$ $(1000 \mathrm{mg} / \mathrm{kg})$ showed liver tissue with central vein congestion and mild fatty change (Figure 1D). In the $\mathrm{Vo} . \mathrm{Cr}(500 \mathrm{mg} / \mathrm{kg})$ treated animals the liver tissue showed periportal hepatocytes drop out, portal vein congestion with no fatty change (Figure 1E). Similar effects were observed with higher dose of Vo.Cr (1000 $\mathrm{mg} / \mathrm{kg}$ ), Figure $1 \mathrm{~F}$. Atorvastatin $(10 \mathrm{mg} / \mathrm{kg})$ treated group showed central vein congestion and no fatty change (Figure 1G).

\section{DISCUSSION}

This study demonstrates the anti-hyperlipidemic effect of Caralluma edulis and Verbena officinalis crude extract. Treatment with Ce.Cr extract and Vo.Cr extract lowered lipid profile and raised the HDL in mice. HFD-induced hyperlipidemia in mice causes increase in plasma TC, TGs, LDL, VLDL and oxidative damage in liver [16]. HFD induced hyperlipidemia decreases $\beta$-oxidation and increases the synthesis of cholesterol and oxidative stress due to decreased free radical scavenger enzymatic gene expression. Plant polyphenols plays a preventive role in cardiovascular diseases including atherosclerosis. Combination of $0.25-0.5 \%$ cholic acid with cholesterol increases cholesterol absorption and produces atherosclerosis in normal mice [17]. Cholic acid plays an important role in liver inflammation and lowers the production of bile acid and affects the TGs and HDL levels which further leads to development of atherosclerosis. Different types of fats are used to provide energy $(20-60 \%)$ derived from either using animal fats (beef tallow or lard) or plant fats oils (coconut or olive oil).

Coconut oil, lard and olive oil cause hepatic steatosis without inflammation [18]. Mice fed with HFD increased the body weight compared to standard diet. HFD induced hepatic steatosis and inflammation begins with presence of leukocytes in the tissue. Hypercholesterolemia causes increase in the production of free radicals and raises levels of lipid peroxides [19]. Myristic acid and lauric acids are present in coconut oil; they increase level of LDL more than HDL. The elevation of the LDL level in animals fed on HFD could be related to changes in hepatic LDL 
receptors. It also causes oxidative stress that further leads to increased oxidized LDL levels.

Stress due to oxidation plays a very magnificent role in the development of cardiac complication, neurodegenerative diseases, and cancer and in the aging process. Flavonoids and terpenoids may reduce $\mathrm{TC}$, TGs, LDL and VLDL through the inhibition of pancreatic lipases which are responsible for the conversion of triglyceride into fatty acids and glycerol [20]. Plants containing polyphenols inhibit lipid peroxidation and increases glutathione peroxidase which prevents tissue damage by neutralizing reactive oxygen species [21]. The total phenolic content of Verbena officinalis was $652.50 \pm 2.36$ Gallic Acid Equivalent (GAE $\mathrm{g} / \mathrm{kg}$ dry mass). The total flavonoids contents were $188.90 \pm 2.5$ quercetin equivalents (QE g/kg of dry mass).

The phenolic and flavonoid contents of these plants might have contributed to the observed beneficial effects on lipid profile in animals fed on HFD. The antioxidant inhibitory concentration was $15.76 \pm 0.8 \mathrm{mg} / \mathrm{L}$ compared to vitamin C 4.4 $\pm 0.2 \mathrm{mg} / \mathrm{L}$ respectively. The anti-hyperlipdemic effect exhibited by Caralluma edulis may be related to its known antioxidant potential and in Verbena officinalis may be due to the presence of phytochemical compounds such as flavonoids, phenolic compounds, terpenoids, phenyl propanoids and iridoids, which were reported to possess radical scavenging activity [22].

\section{CONCLUSION}

The current study reveals that Caralluma edulis and Verbena officinalis crude extracts possess anti-hyperlipidemic potential against HFDinduced hyperlipidemia. Further advanced studies were needed to identify the active principles accounting for anti-hyperlipidemic effect and to elucidate the possible mechanism of action.

\section{DECLARATIONS}

\section{Acknowledgement}

The authors acknowledge the financial support of Prince Abdullah Ben Khalid Celiac Disease Research Chair, Vice Deanship of Research Chairs, King Saud University Riyadh Saudi Arabia.

\section{Conflict of Interest}

No conflict of interest associated with this work.

\section{Contribution of Authors}

The authors declare that this work was done by the authors named in this article and all liabilities pertaining to claims relating to the content of this article will be borne by them.

\section{Open Access}

This is an Open Access article that uses a funding model which does not charge readers or their institutions for access and distributed under the terms of the Creative Commons Attribution License (http://creativecommons.org/licenses/by/ 4.0) and the Budapest Open Access Initiative (http://www.budapestopenaccessinitiative.org/rea d), which permit unrestricted use, distribution, and reproduction in any medium, provided the original work is properly credited.

\section{REFERENCES}

1. Gerhardt AL, Gallo NB. Full-fat rice bran and oat bran similarly reduce hypercholesterolemia in humans. J Nutr 1998; 128(5): 865-869.

2. Phogat $P$, Deep A, Sharma PC, Sanjeev K, Mittal SK, Kakkar S, Goyal R, Thakral K. Introduction to hyperlipidemia and its management. Rev Pharmacol online 2010; 2: 251-266.

3. Nickolas TL, Radhakrishnan J, Appel GB. Hyperlipidemia and thrombotic complications in patients with membranous nephropathy. Semin Nephrol 2003; 23(4): 406-411.

4. Sofowora A. Medicinal plant and traditional medicine in Africa. Ibadan: Spectrum Books, 1996: 112.

5. Mishra PR, Panda PK, Apanna KC, Panigrahi $S$. Evaluation of acute hypolipidemic activity of different plant extracts in Triton WR-1339 induced hyperlipidemia in albino rats. PhOL 2011; 3: 925-934.

6. Adnan M, Jan S, Tariq A, Begum S, Afroz A, Shinwari ZK. A review on ethnobotany, phytochemistry and pharmacology of plant genus Caralluma $R B r . J$ Pharmacol 2014; 66 (10): 1351-1368.

7. Wadood A, Wadood N, Shah SA. Effects of Acacia arabica and Caralluma edulis on blood glucose levels of normal and alloxan diabetic rabbits. J Pak Med Assoc 1989; 9: 208-212.

8. Ansari NM, Houlihan L, Hussain B, Pieroni A. Antioxidant activity of five vegetables traditionally consumed by South-Asian migrants in Bradford, Yorkshire, UK. Phytother Res 2005; 10: 907-911.

9. Nasir E, Ali Sl. Flora of West Pakistan. Karachi: University of Karachi, 1983: 1-62.

10. Bilia AR, Giomi M, Innocenti M, Gallori S, Vincieri FF. HPLC-DAD-ESI-MS analysis of the constituents of aqueous preparations of verbena and lemon verbena and evaluation of the antioxidant activity. $J$ Pharm Biomed Sci 2008; 46: 463-470. 
11. Williamson EM, Okpako DT, Evans FJ. Selection, preparation and pharmacological evaluation of plant material. Chichester, UK: John Wiley and Sons, 1998:15-23.

12. Principles of Laboratory Animal Care (NIH Publication $85-$ 23, revised 1985).

13. Evans WC. Trease and Evans Pharmacognosy. London: WB Saunders, 1996.

14. Park E, Baek A, Kim M, Lee SW, Lee E, Choi MJ, Lee J, Song YO. Inhibitory effect of functional Sujeonnwa (Cinnamon Drink) on lipid peroxidation and DNA damage in diet induced hypercholesterolemic Apo $E$ Knockout Mice. J Korean Soc Food Sci 2015; 9: 16271634.

15. Friedewald WT, Levy RI, Fredrickson DS. Estimation of the concentration of low density lipoprotein. Clin Chem 1972; 18: 499-502.

16. Yan MX, Yan-Qing L, Min M, Hong-Bo R and Yi K. Longterm high-fat diet induces pancreatic injuries via pancreatic microcirculatory disturbances and oxidative stress in rats with hyperlipidemia. Biochem Biophys Res Comm 2006; 347(1): 192-199.

17. Nishina, PM, Lowe S, Verstuyft J, Naggert JK, Kuypers $F A$, Paigen B. Effects of dietary fats from animal and plant sources on diet-induced fatty streak lesions in C57BL/6J mice. J Lipid Res 1993; 34: 1413-1422.

18. Buettner R, Parhofer KG, Woenckhaus M, Wrede, CE, Kunz-Schughart LA, Scholmerich J, Bollheimer LC. Defining high-fat-diet rat models: metabolic and molecular effects of different fat types. $\mathrm{J}$ Mol Endocrinol 2006; 36: 485-501.

19. El-Beshbishy HA, Singab ANB, Sinkkonen J, Pihlaja $K$. Hypolipidemic and antioxidant effects of Morus alba $L$. (Egyptian mulberry) root bark fraction supplementation in cholesterol-fed rats. Life Sci 2006; 78: 2724-2733.

20. Morikawa T, Xie Y, Asao Y, Okamoto M, Yamashita C, Muraoka $O$, Matsuda $H$, Pongpiriyadacha $Y$, Yuan $D$, Yoshikawa M. Oleanane-type triterpene oligoglycosides with pancreatic lipase inhibitory activity from the pericarps of Sapindus rarak. Phytochem 2009; 70: 1166-1172.

21. Wellwood CRL, Cole RA. Relevance of carnosic acid concentrations to the selection of rosemary, Rosmarinus officinalis (L.), accessions for optimization of antioxidant yield. J Agric Food Chem 2004; 52: 6101-6107.

22. Xin F, Jin YS, Sha $Q, X u W, Z u Z, L i$ YS. Chemical constituents isolated from Verbena officinalis. Chin Med J 2008; 10: 21-23. 